\title{
Manipulating the media: a historian's view
}

Peter BURKE ${ }^{1}$

\begin{abstract}
:
This article deals with media manipulation in a historical perspective. Part of the concepts of post-truth and fake news to analyze propaganda and the impression management over time, with the main focus being the construction of the image of Louis XIV. The text brings together the main ideas discussed by the author at the opening conference of the 11th National Meeting of Media History - Alcar 2017, held in São Paulo (Brazil).

Keywords:

Media history. Communication history. Media manipulation.
\end{abstract}

\section{Manipulando a mídia: a visão de um historiador}

Resumo:

Este artigo aborda a manipulação midiática em uma perspectiva histórica. Parte dos conceitos de pósverdade e fakenews para analisar a propaganda e o gerenciamento de imagens e impressões ao longo do tempo, tendo como foco principal a construção da imagem de Louis XIV. O texto reúne as principais ideias discutidas pelo autor na conferência de abertura do $11^{\circ}$ Encontro Nacional de História da Mídia - Alcar 2017, realizado em São Paulo (Brasil).

Palavras-chave:

História da mídia. História da comunicação. Manipulação midiática.

\section{Manipular losmedios: lavisión de un historiador}

Resumen:

Este artículo trata sobre lamanipulación de losmedios desde una perspectiva histórica. Parte de los conceptos de post-verdad y fakenews para analizarla propaganda y lagestión de imágenes y impresiones a lo largo deltiempo, conel enfoque principal enlaconstrucción de laimagen de Louis XIV. El texto reúne lasprincipalesideas discutidas por el autor enla conferencia de apertura del $11^{\circ}$ Encontro Nacional de Historia da Mídia - Alcar 2017, realizado en São Paulo (Brasil).

Palabras clave:

Historia de losmedios de comunicación. Historia de lacomunicación. Manipulación mediática.

\section{Introduction}

In the last few years, the idea has spread that we are living in a 'post-truth era'. A book with the title 'Post Truth' was published this year by a British journalist, Matthew D'Ancona (2017). Another phrase that has recently become popular is that of 'Fake News', popularized by the tweets of President Trump who claims both that he invented the phrase and that the accusation that he won the election with Russian support is an example of the phenomenon (PHILLIPS, 2017; CILLIZZA, 2017). A similar claim, not

\footnotetext{
${ }^{1}$ Peter Burke holds the title of Professor Emeritus at the University of Cambridge. He studied at Oxford and taught at the university of Sussex before going to Cambridge in 1979. He was a Fellow at the Institute of Advanced Study, Princeton, in 1969, and at the Wissenschaftskolleg, Berlin, in 1989-90. In Brazil, he was a visiting professor at the Institute of Advanced Studies of the University of São Paulo in the 1990's. E-mail: upb1000@cam.ac.uk
} 
quite so radical, is that we live in an age of 'spin', in which politicians such as Tony Blair or Vladimir Putin and their advisers, the so-called 'spin doctors', manipulate the facts rather than inventing them ex nihilo. A French TV series, Les hommes de l'ombre, shown in 2012, centred on two rival figures of this kind. When the series was shown on British television in 2016, the title was translated as 'Spin' (a kind of euphemism, since 'spinning' the news sounds better than the older term, 'twisting' it).

How do these claims look in historical perspective? There are two possibilities. The first is that we are indeed experiencing a major change in politics or the media or in everyday life, or in all of these. The second possibility is that these claims are simply new examples of the exaggerations that historians often impute to journalists (whether they work on paper, on air, or on screen). Exaggeration, or hype, is part of the déformationprofessionelle of journalists, who make their living from the news and tend to assert (especially, of course, in headlines), that almost everything that happens is the first of its kind, the beginning of a new era, that the world will never be the same again, etc. This kind of exaggeration is particularly obvious to historians, because their déformationprofessionelle is exactly the opposite, stressing continuity and sometimes even asserting that there is nothing new under the sun.

In what follows, I shall try to steer between the two extremes of 'everything is different' and 'nothing is different'. For this purpose I shall tell the story backwards, from the present moment to the 17 th century or even beyond.

\section{Concepts}

Let's begin with the concepts. The idea of 'post-truth' was not invented in 2017, as D'Ancona himself admits. A book on 'The Post-Truth Era' was published in 2004, while the phrase seems to have been coined twelve years earlier, in 1992. The phrase 'spin doctors' was employed in the New York Times in the 1940s. An essay on Fascist propaganda by George Orwell, published in 1942, was, according to D'Ancona, 'an early premonition of the Post-Truth era' (KEYES, 2004; GREENBERG, 2016; D’ANCONA, 2017).

Other analysts have made similar points in different words. In France, Jean Baudrillard discussed what he called 'hyper-reality' and notoriously claimed in 1991 that the first Gulf War was simply a media event, that La guerre du Golfen'a pas eulieu 
(BAUDRILLARD, 1991) ${ }^{2}$. In the USA, the historian Daniel Boorstin had already used the term 'pseudo-event' in 1961, with a similar meaning, in a book entitled The image. An alternative formulation was offered by Roger-Gérard Schwartzenberg in a book entitled L'état-spectacle (1977), on the rise of what he called the 'star system' in politics (the title presumably alludes to an earlier and more famous study, Guy Debord's $L a$ société du spectacle (1967). Future historians will probably discuss these books, among many others published in the late 20th and early 21 st centuries, as examples or symptoms of postmodernity.

In my opinion, which I shall attempt to support in what follows, the claims to novelty made by this group of scholars and theorists are exaggerated, at times wildly so. It is time to introduce an older concept, 'propaganda', which has been current from the French Revolution onwards and became increasingly important in the age of Soviet Russia (when there was a Department for Agitation and Propaganda, known for short as Agitprop) and Fascist Italy (when the official title of Galeazzo Ciano was 'Minister of the Press and of Propaganda'). In the USSR, during the Moscow Trials of 1936-8, leading Bolsheviks such as Grigory Zinoviev and Nikolai Bukharin were accused of treason, but the 'evidence' was clearly manufactured by the secret police. More generally, in the postwar USSR, the public distrusted the official newspapers Pravda and Izvestia and relied on word of mouth communication instead (BAUER; GLEICHER, 1953). The joke that itself circulated by word of mouth was that there was 'no news (izvestia) in Pravda, and no truth (pravda) in Izvestia'.

An even older concept is that of 'lies' (JAY, 2010; D'ANCONA, 2017). The British journalist Jeremy Paxman, who has interviewed many politicians, has said that on each occasion he used to ask himself 'Why is this lying bastard lying to me?', a phrase that is attributed to the American journalist Louis Heren (1919-95) (WHY..., 2014; HEREN, 2017). Let me take a single notorious example of lies in the Communist world. After 1945 the massacre of more than 20,000 Polish officers by the Russian secret police in the forest of Katyn in the spring of 1940 was officially attributed to the Nazis. The Poles knew what had really happened, but during the Communist period the government engaged in a process of what has been described as 'discursive cleansing', silencing the unofficial stories so far as possible (FINNIN, 2012). The story of both the

\footnotetext{
${ }^{2}$ Jean Baudrillard, La guerre du Golfen'apaseulieu (Paris, 1991), playingonthetitleof a playby Jean Giraudoux, La guerre de Troien'aurapaslieu (1935).
} 
massacre and the lies about the massacre was retold much later by the famous Polish director Andrzej Wajda in his film Katyń (2007).

It would also be possible to argue in this way on the basis of evidence from the 18 th and 19th centuries, or indeed the 16th century, but I shall concentrate on the representation of politics - and the politics of representation - in the age of Louis XIV of France, a topic on which I published a book in English in 1992. At this point I should make a confession. My approach to the 17 th century was inspired by a news report that Margaret Thatcher had consulted the famous advertising agency Saatchi and Saatchi (as the agency was known at the time) in order to improve her public image and so win more votes. In my study, I referred to the books by Schwarzenberg and Boorstin, already cited, criticizing the idea of the novelty of L'état-spectacle but making use of the concept of the pseudo-event. I was also inspired by the sociologist Erving Goffman and his famous study The presentation of self in everyday life (1956). To conclude this confession, I borrowed the title of my book, The Fabrication of Louis XIV, from an Italian study of Mussolini, La fabbrica del Duce (BIONDI, 1967).

\section{Choosing a topic}

Why choose Louis XIV in particular? He is certainly not the first example of what Goffman called 'impression management', a process that might be described in the case of rulers with a useful oxymoron, 'collective self-representation of individuals'. Think of ancient Egypt, for instance, and the representations of the Pharaohs. Again, think of Augustus Caesar, and the statues of himself that could be found all over the Roman Empire, showing the emperor in almost identical fashion and in idealized form, since Augustus was always represented as a young man throughout his long reign (forty years in power) (ZANKER, 1987 [1990]). Ancient Greeks and Romans were at least as skilled in rhetoric, the art of persuasion (or spin?), as their successors today.

Yet again, think of the emperor Charles V, and of the role of leading artists such as Titian in disseminating idealized images of the 16th-century ruler (BURKE, 1999). And remember Machiavelli and his advice to princes in his treatiseDe principe that the great majority of mankind are satisfied with appearances, as though they were realities and are often more influenced by the things that seem than by those that are'. Machiavelli shocked his readers not because he expressed a new idea but because he gave the game away, making public the secrets of rulers. 
From the seventeenth century, I might have chosen England as a case-study rather than France, since the reign of Charles II witnessed one of the most spectacular cases of what we are beginning to call 'Fake News': the so-called 'Popish Plot', supposedly a plan of the Catholics, led by Jesuits to assassinate the king. The story, made public in 1678, and widely believed, was a fabrication by a disgraced Anglican clergyman, Titus Oates, who had already been accused of perjury. After three years of treatment as a hero, Oates was unmasked as a liar and imprisoned. The best-known study of the Popish Plot, written by the historian John Kenyon, is marked by both robust common sense and traditional empiricism. The book vividly illustrates both the strengths and weaknesses of such an approach. Concerned simply to elucidate what actually happened (or failed to happen), Kenyon concentrates on showing that there never was any plot, dismissing contemporary beliefs in it as irrational, as 'panic', as 'hysteria'. It would be illuminating to see an analysis of the reception of the story of the plot from the point of view of a historian of the media, offering a case-study of the effects of rumour. This case is a clear illustration of the well-known theory that rumour flourishes when the supply of information is inadequate to meet the demand for it, the official newspaper, the Gazette, did not mention the plot at all, while unofficial newspapers were prohibited at this time (KENYON, 1972; SHIBUTANI, 1966).

I chose Louis XIV as a case-study of impression management for three main reasons. The first reason was the number of representations of the king that circulated in his time in a great variety of media and genres: paintings, statues, triumphal arches, engravings, medals, tapestries, newspapers, poems, plays, ballets, operas, histories, rituals and so on. The everyday life of rulers has often been transformed into a kind of theatre, but the life of Louis, especially when he was in his palace of Versailles, was even more theatrical than that of his predecessors or his fellow-monarchs in other countries. In short, the 'star system' already existed, and the greatest political star was the Sun King.

The second reason for choosing Louis was that the creation of both literary and visual images of the king was more thoroughly organized than, so I believe, it had ever been in the reigns of his predecessors in France or elsewhere. A committee was formed in order to supervise the production of these images, making this small group of men of letters the ancestors of today's hommes de l'ombre, working behind the scenes of the political stage. The third reason for choosing Louis was the relative wealth of 
documentation of the process of impression management, thanks in part to the existence of the committee just mentioned.

\section{The image of Louis $\mathrm{XIV}^{3}$}

Turning now to the way in which Louis XIV was presented in public, I should like to distinguish two forms of presentation. The first was relatively traditional, presenting the monarch as a kind of hero. The second form, which was relatively new, attempted to impose official interpretations of events on the public, in other words, to manipulate both the media and its audience.

To begin with the heroic image. In texts, Louis was described as generous, heroic, just, magnanimous, munificent, pious and wise, and even as invincible, immortal, the most powerful monarch of the universe (conveniently forgetting the emperor of China) and as 'our God on earth'. In a word, he was 'great', an adjective officially adopted and written in capital letters. Louis was also proclaimed a new Augustus, a new Charlemagne, a new Constantine, a new Solomon and, the comparison that the young king liked best, a new Alexander. Louis was also compared to Jupiter, Mars, Apollo and of course to the sun.

Who wrote these praises? The authors were usually French poets and historians, among them the dramatist Jean Racine. However, the king's advisers also hired foreigners to praise Louis. The point of doing this was, as one adviser once explained in a private letter, because it "was important for the honour of His Majesty that the praises appeared to be spontaneous, and in order to appear spontaneous they needed to be printed outside his kingdom'. Another relatively indirect medium for the praise of the king was the Mercure Galant, founded in 1672, an early example of a magazine mainly concerned with fashion. Its editor received a pension for his political work.

Louis was also idealized in visual media such as paintings, statues and engravings. The most famous of these images, painted towards the end of his reign, is the portrait painted by Hyacinthe Rigaud. Unlike Augustus, Louis allowed himself to be shown in this portrait as growing old, with a shrunken mouth. All the same, his body seems young -the pose of the feet, reminded viewers that Louis had been a great dancer in his youth. The high heels of the king are also worth noting, necessary because Louis

${ }^{3}$ For details, see Peter Burke, The fabrication of Luis XIV (New Haven, 1992).Portuguese translation: Peter Burke,A fabricação do rei: a construção da imagem pública de Luís XIV. Rio de Janeiro: Jorge Zahar, 1994. 
was a short man (like Napoleon and also Nicolas Sarkozy, who has also been known to wear high heels on occasion). In the Rigaud portrait the emphasis is on dignity, embodied in the robes and the objects with which the king is associated - the crown, sceptre, sword, classical column and red velvet curtain.

The emphasis is rather different in another famous image, displayed in the palace of Versailles, showing Louis as a victorious warrior, dressed as a Roman general (with the addition of a 17th-century wig) and riding over the bodies of his enemies, thus offering a dramatic example of triumphalist visual rhetoric. I should add at this point that it was well known that Louis never led his troops into battle, unlike some other kings at this time.

Let me now turn to techniques of self-presentation that were relatively new in this period. Although the word 'propaganda' is technically an anachronism, I still think that it is useful in order to describe an attempt to impose an official interpretation of events, as they occurred and also years or decades later.

The principal means to this effect was the medal, combining the representation of an event with a short inscription that can be read as an instruction to the viewers, telling them how to interpret that event. No fewer than 286 medals of this kind were cast during the king's reign. Some of the inscriptions read like later newspaper headlines: 'two million Calvinists brought back to the Church', for instance, VICIES CENTENA MILLIA CALVINIANORUM AD ECCLESIAM REVOCATA (1685), or 'Twenty towns on the Rhine taken by the Dauphin in a single month', VIGINTI URBES AD RHENUM A DELPHINO UNO MENSE SUBACTAE (1688). The medals themselves were cast in bronze in 50 or 100 copies, but engravings of the medals, collected into volumes, ensured that they were seen by many more people. These volumes were known as the 'medallic histories' of the reign.

When the French fleet attacked the city of Algiers, for instance, claiming to suppress the activities of pirates, a medal was struck showing a humble Africa at the feet of a victorious Louis together with the cannon that had bombarded the city. Again, the ambassadors of the King of Siam were represented as grovelling at the feet of the King of France, while the inscription emphasizes that the ambassadors arrived in France thanks to the fame of the king's virtues. It does not seem unreasonable to describe the king's advisers as 'spinning' events.

In these two cases, both of them telling the public that the fame of the king had 
spread outside Europe, the events were real even if the interpretation of those events could be questioned. In other cases, events were created by the media themselves. A statue of the king as a conqueror was erected in one of the main squares of Paris, and a medal was struck to commemorate this. In other words, the celebration of Louis in one of the media was itself celebrated in another of the media. In yet a third type of case, the media represented a 'pseudo-event', something that had not taken place. The most notorious example is the engraving showing Louis visiting the French Academy of Sciences, thus showing him as a patron of learning. However, historians have discovered that this visit never took place.

A recent study of narratives refers to what the author calls 'story wars' (SACHS, 2012). The phrase is an appropriate one for referring to the 'counter-propaganda' launched by the Dutch, English and Germans at a time when these countries were indeed at war with France. The great coup in this war of ideas was the publication by the Dutch of a new edition of the medallic history in which they inserted a few satirical engravings, in one of which you see the king preferring love to war, leaving the battlefield accompanied by four of his mistresses. The book circulated in France for a time before readers became suspicious!

\section{Conclusions}

I have been making comparisons between the public image of Louis XIV and the image of more recent rulers. There were also, of course, some major contrasts. France was not a democracy, so Louis did not need votes. The audience that he and his advisers wanted to impress was not the people but foreign rulers, the French aristocracy, and posterity. His cultural capital was his dignity. In the 20 th and 21 st centuries, on the other hand, rulers need to appeal to the people, to present themselves as virile. Hence the public presentation of bare-chested images of Mussolini, of Collor and more recently and frequently - of Putin.

To conclude, I should like to return to the question that I posed at the beginning of this article. Are we living in a new age, the age of post-truth, or not? Any answer to this question needs to distinguish between new methods and old aims. If, as Marshall McLuhan used to say, 'the medium is the message', we are living at a time of revolution in which Facebook is transforming the public as well as the private sphere, while searchers online are manipulated by search engines such as Google (HALAVAIS, 2009). 
Although measurement is difficult, it is likely that the amount of fake news, or public lies, in circulation is increasing, as well as circulating at a higher speed than in the past (although the rapidity of old-fashioned rumour should not be underestimated).

On the other hand, if the message also matters, there is plenty of evidence of continuity. As usual, a simple binary contrast between one period and another, or between truth and lies, is less illuminating than a more nuanced approach, asking whether more fake news is in circulation than 20 years ago or speaking of messages that are more or less true, that correspond more or less closely to the evidence. We need to avoid what psychologists call 'hysteria' or what sociologists call a 'moral panic', in other words an irrational fear of a threat to society from devils who range from Catholics, Communists and Muslims to youth groups and bankers (COHEN, 1972).

The good news, in my view is that an increasing awareness of fake news, encouraged by the discussion of the topic in the media, encourages critical attitudes to texts. There is a need for training in this kind of criticism at school level, teaching students to ask where the speakers are speaking from, what are their agenda, their sources. This makes me think of a memorable phrase uttered by a witness at the Profumo trial of 1963, a notorious British political scandal. The witness claimed to have had sex with a well-known politician. He denied it. Asked about the denial, the witness, Mandy Rice-Davies, remarked: 'He would, wouldn't he?' In Britain, the phrase has become a kind of proverb ${ }^{4}$. Images also need to be examined critically in this way (KOSSOY, 1999; BURKE, 2004).

Half a century ago, Umberto Eco called for 'semiological guerrilla warfare' against the economic or political control of communications (ECO, 1967). 70 years ago, Ernest Hemingway, a journalist as well as a novelist, remarked on the need for individuals to have their own 'crap detector' (POSTMAN, 1969). One of the tasks of educators is surely to show students how to build such a detector for themselves, a new but necessary form of conscientização. You may remember that this process was dramatically illustrated by an Argentinian film, La historiaoficial (directed by Luis Puenzo, 1985), in which the protagonist, the history teacher Alicia, finally learns to disbelieve the stories told about itself by the military regime. If we cannot change the manipulation of the media, we can at least do something to change the way in which viewers, listeners and readers respond to it.

\footnotetext{
${ }^{4}$ Sometimessummarized as MRDA, 'Mandy Rice-Davies Applies'.
} 
References

BAUDRILLARD, Jean. La guerredu Golfe n'a pas eu lieu. Paris: Galilé, 1991.

BAUER, Raymond A.; GLEICHER, David B. Word-of-MouthCommunication in the Soviet Union, PublicOpinionQuarterly, 17, p. 297-310, 1953.

BEWES, Timothy. The spin cycle: truth and appearance in politics. Signsofthe Timeswebsite. 1999. Available in:

<http://www.signsofthetimes.org.uk/pamphlet1/The\%20Spin\%20Cycle.html>.

BIONDI, Dino. La fabbricadelDuce. Florence: Vallecchi, 1967.

BOORSTIN, Daniel. Theimage: orwhathappenedtothe American dream. New York: Atheneum, 1962.

BURKE, Peter. Testemunha ocular: história e imagem. Bauru, SP: Edusc, 2004.

BURKE, Peter. Presenting and re-presenting Charles V. In: SOLY, Hugo (Ed.). Charles V, 1500-1558 and his time. Antwerp: Mercatorfonds, 1999, p. 393-475.

CILLIZZA, Chris. Donald Trump just claimed he invented 'fake news'. CNN, Politics. Oct. 26, 2017. Available in: <edition.cnn.com/2017/10/08/politics/trump-huckabeefake/index.html>. Visited in: 30 Oct. 2017.

COHEN, Stanley. Folk devils and moral panics: thecreationofthe mods and rockers. London:MacGibbon\&Kee, 1972.

D'ANCONA, Matthew. Post-truth: the new warontruth and howtofight back. London: EburyPress, 2017.

DEBORD, Guy. La société du spectacle. Paris: Buchet-Chastel, 1967.

ECO, Umberto. Towards a semiological guerrilla warfare. [First given as a lecture at the conference Vision'67, New York, 1967]. Available in: <http://www.kareneliot.de/downloads/UmbertoEco_Towards\%20a\%20Semiological\%2 0Guerrilla\%20Warfare.pdf $>$. Visited in: 31 Oct. 2017.

FINNIN, Rory. Katyn in Poland. In: ETKIND, Alexander; FINNIN, Rory et al..RememberingKatyn. Cambridge: PolityPress, 2012, p. 13-34.

GIRAUDOUX, Jean. La guerre de Troien'aurapaslieu. Paris: Bernard Grasset, 1935.

GREENBERG, David. A century of political spin. The Wall Street Journal. Jan. 8, 2016. Available in: <http://www.wsj.com/articles/a-century-of-political-spin1452267989>.

GREENBERG, David. Republic of Spin: an inside history of the American Presidency. New York: W.W. Norton \& Company, 2017. 
HALAVAIS, Alexander. Searchenginesociety. Cambridge: Polity, 2009.

HEREN, Louis. Wikipedia. June 14, 2017. Available in: <https://en.wikipedia.org/wiki/Louis_Heren>.Visited in: 30 Oct. 2017.

JAY, Martin. Thevirtuesofmendacity: onlying in politics. Charlottesville VA: Universityof Virginia Press, 2010.

KENYON, John. ThePopishPlot. London: Phoenix Press, 1972.

KEYES, Ralph. The Post-Truth Era: dishonesty and deception in contemporary life. New York: St. Martin's Press, 2004.

KOSSOY, Boris. Realidades e ficções na trama fotográfica. São Paulo: Ateliê editorial, 1999.

MARR, Andrew. How Blair put the media in a spin. BBC News. 10 May 2007. Available in: <news.bbc.co.uk/2/hi/uk_news/politics/6638231.stm>.

OSTROVSKY, Arkady.The invention of Russia: the journey from Gorbachev's freedom to Putin's war. London: Atlantic Books, 2016.

PHILLIPS, Amber. With money laundering charges against Paul Manafort, Trump's 'fake news' claim is harder to defend. The Washington Post, Washington, DC, October 30, 2017. Available in: <https://www.washingtonpost.com/news/thefix/wp/2017/10/30/with-this-paul-manafort-indictment-trumps-fake-news-defense-haszero-credibility/?utm_term $=.788 \mathrm{f} 3 \mathrm{c} 92450 \mathrm{~b}>$.

POMERANTSEV, Peter. Nothing is true and everything is possible: the surreal heart of the new Russia. London: Public Affairs, 2014, second edn, 2017.

POSTMAN, Neil. Bullshit and the art of crap-detection. [Delivered at the National Convention for the Teachers of English, Nov. 28, 1969, Washington, D.C.]. Available in: $<$ https://criticalsnips.wordpress.com/.../neil-postman-bullshit-and-the-art-of-crapdetecti>. Visited in: 31 Oct. 2017.

RAVIN-HAVT, Ari; MEDIA MATTERS FOR AMERICA. Lies, Incorporated: theworldof post-truthpolitics. New York: Knopf Doubleday Publishing Group, 2016.

SACHS, Jonah. Winningthestorywars: whythosewhotell - and live - thebeststorieswill rule thefuture. Boston, MA: Harvard Business ReviewPress, 2012.

SCHWARTZENBERG, Roger-Gérard. L'État-Spectacle. Essaisur e contrele Star System en politique. Paris: Flammarion, 1977.

SHIBUTANI, Tamotsu. Improvised news: a sociologicalstudyof rumor.Indianapolis: TheBobbs-Merrill Company, 1966.

WHY isthislyingbastardlyingtome?.TheNewsroom Blog. 02 July 2014. Availablein: <blogs.bl.uk/thenewsroom/2014/07/why-is-this-lying-bastard-lying-to-me.html. 
ZANKER, Paul. Thepowerofimages in the Age ofAugustus. 1987, Englishtranslation. Ann Arbor, 1990.

Submetidoem: 02.04.2018

Aprovadoem: 06.06.2018 